\title{
ETNOBOTANI TUMBUHAN OBAT MASYARAKAT DESA MANIS MATA KABUPATEN KETAPANG
}

\section{ETNOBOTANY MEDICINAL PLANTS IN THE VILLAGE OF MANIS MATA KETAPANG DISTRIC}

\author{
Sangga Saputra*, Syamswisna* dan Reni Marlina \\ Fakultas Keguruan dan IImu Pendidikan, Universitas Tanjungpura
}

Keywords:

Etnobotany,

Medicinal herbs, Manis Mata Village
Kata Kunci:

Etnobotani,

Tumbuhan obat,

Desa Manis Mata

\begin{abstract}
The local wisdom of the people of Manis Mata Village in utilizing plants as traditional medicine is still widely practiced. Public knowledge about medicinal plants is passed down from generation to generation. The people of Manis Mata Village make a lot of use of traditional medicinal plants, but there is no documented data that it is feared that the natural habitat of the plants will be lost due to forest fires, logging of trees, clearing of oil palm land and other natural disasters. The purpose of this study was to determine the types of plants used as traditional medicine by the people of Manis Mata Village. The research method used is descriptive method with triangulation data collection techniques, namely observation, interviews and documentation. Information about medicinal plants was obtained from 94 informants consisting of traditional healers, and people in Manis Mata Village. The results of the research obtained 46 medicinal plant species consisting of 26 families and the most widely used part of the leaves and plants which were most commonly found as medicine was the families
\end{abstract}

\begin{abstract}
ABSTRAK
Kearifan lokal masyarakat Desa Manis Mata dalam memanfaatkan Tumbuhan sebagai obat Tradisional masih banyak dilakukan. Pengetahuan masyarakat tentang Tumbuhan obat diwariskan secara turun-temurun. Masyarakat Desa Manis Mata banyak memanfaatkan tumbuhan obat tradisional, tetapi belum ada data yang didokumentasikan dikhawatirkan habitat alami tumbuhan akan hilang akibat kebakaran hutan, penebangan pohon, pembukaan lahan kelapa sawit dan bencana alam lainnya. Tujuan penelitian ini untuk mengetahui jenis-jenis tumbuhan yang dimanfaatkan sebagai obat Tradisional oleh masyarakat di Desa Manis Mata. Metode penelitian yang digunakan metode deskriftif dengan teknik pengumpulan data triangulasi yaitu observasi,wawancara dan dokumentasi. Informasi tentang tumbuhan obat diperoleh dari 94 orang informan yang terdiri dari pengobat Tradisional, dan masyarakat di Desa Manis Mata dari hasil penelitian diperoleh 46 spesies tumbuhan obat yang terdiri 26 famili serta bagian yang paling banyak digunakan daun dan tumbuhan yang paling banyak ditemukan sebagai obat yaitu famili zingiberaceae
\end{abstract}

Corresponding Author : Syamswisna@fkip.untan.ac.id 


\section{PENDAHULUAN}

Etnobotani merupakan ilmu botani yang mempelajari tentang pemanfaatan tumbuhtumbuhan dalam keperluan hidup seharihari dan adat suku bangsa. Kelompok etnik ini memanfaatkan tumbuhan-tumbuhan yang berguna untuk berbagai kepentingan. Diantaranya sebagai bahan pangan, obatobatan,tali-temali dan bahan perlengkapan dalam upacara adat. Bentuk pengetahuan masyarakat tradisional diturunkan secara turun temurun (Uddin dkk, 2013)

Berdasarkan hasil observasi yang telah dilakukan di balai desa, Desa Manis Mata merupakan desa yang terdapat di Kabupaten Ketapang, Provinsi Kalimantan Barat. Desa ini memiliki luas wilayah sebesar $105 \mathrm{~km}$, terdiri atas beberapa dusun yaitu Dusun Beriam memiliki 198 kepala keluarga, Dusun Amor 57 kepala kelurga, Dusun Tengkawang memiliki 344 kepala keluarga dan Desa Manis Mata memilki 333 kepala keluarga sehingga jumlah keseluruhan penduduk Desa Manis Mata adalah 932 kepala keluarga. Penduduk yang tinggal di Desa Manis Mata merupakan masyarakat yang terdiri dari beberapa suku yaitu suku Jawa sebanyak 10,94\%, suku Thionghoa sebanyak 0,32\%, suku Bugis sebanyak $1,07 \%$, suku Dayak sebanyak 28,43\% dan suku Melayu (mayoritas) sebanyak 59,22\% (Arsip Desa Manis Mata, 2018).

Masyarakat Desa Manis Mata banyak memanfaatkan tumbuhan obat tradisional, tetapi belum ada data yang didokumentasikan dikhawatirkan habitat alami tumbuhan akan hilang akibat kebakaran hutan, penebangan tidak tebang pilih, pembukaan lahan kelapa sawit dan bencana alam lainnya. hasil wawancara dengan masyarakat setempat yang berjumlah 10 orang menyatakan bahwa masyarakat desa ini masih menggunakan tumbuhan sebagai obat dalam mengatasi berbagai penyakit. Masyarakat menganggap bahwa tumbuhan obat mudah didapatkan untuk penyembuhan. Khasiat tumbuhan obat telah terbukti dengan pemakaian yang terus menerus oleh masyarakat sehingga budaya untuk penambahan penanaman tumbuhan obat secara pribadi hingga saat ini (Auliani, 2014)

Pengetahuan masyarakat Manis Mata tentang tumbuhan obat ini masih terpelihara karena merupakan tradisi turuntemurun dari keluarga, sebagai obat tradisional. juga dipandang lebih aman dikonsumsi dibanding obat kimia, adanya penyakit yang tidak dapat disembuhkan dengan

obat modern, tetapi dapat disembuhkan dengan obat tradisional menyebabkan masyarakat Desa Manis Mata semakin percaya dengan pengobatan tradisional tersebut (Dusun Tengkawang 23 Febuari 2020, wawancara).

Pengetahuan generasi muda tentang pemanfaatan tumbuhan sebagai obat- 
obatan masih rendah sehingga lamakelamaan menyebabkan pengetahuan tersebut akan hilang, kurangnya pengetahuan tentang potensi sumber daya hayati khususnya tumbuhan obat dapat mengakibatkan terjadinya kepunahan.

Penelitian tentang pemanfaatan tumbuhan obat di Kalimantan Barat banyak dilakukan, diantaranya penelitian yang dilakukan oleh penelitian Haryono, Wardenaar dan Yusro (2014) tentang Etnobotani Tumbuhan Obat di Desa Mengkiang Kecamatan Sanggau Kapuas Kabupaten Sanggau memperoleh 60 jenis tumbuhan yang digunakan sebagai obat tradisional. Indra, Husni dan Sisilia (2014) tentang Kajian Etnobotani Tumbuhan Obat Etnis Melayu di Desa Sungai Baru dan Desa Sempadian Kabupaten Sambas memperoleh 73 jenis spesies tumbuhan yang digunakan sebagai obat tradisional.

Berdasarkan permasalahan tersebut, maka peneliti tertarik untuk melakukan penelitian tentang Etnobotani Tumbuhan Obat Masyarakat Desa Manis Mata Kabupaten Ketapang.

\section{BAHAN DAN METODE}

Penelitian ini dilakukan di Desa Manis Mata Kabupaten Ketapang Kalimantan Barat dan dilaksanakan pada bulan Januari-Febuari 2020. Metode penelitian yang digunakan adalah metode deskriptif dan teknik pengumpulan data dengan cara triangulasi yang merupakan gabungan dari wawancara, observasi dan dokumentasi. Data yang dicatat dari ISSN-P : 1978-6417; ISSN-E : 2580-5991 tumbuhan obat adalah nama lokal, tempat tumbuh, penyakit yang diobati, bagian tumbuhan yang digunakan, dan cara penggunaanya.

\section{HASIL}

Sebanyak 46 spesies tumbuhan yang digunakan masyarakat Desa Manis Mata Kabupaten Ketapang.

\section{Bagian tumbuhan yang digunakan sebagai obat tradisional oleh \\ Masyarakat Desa Manis Mata}

Bagian tumbuhan yang digunakan sebagai Obat Tradisional oleh masyarakat di Desa Manis Mata Kabupaten Ketapang yaitu rimpang, buah,batang, daun, bunga, dan tunas. Bagian terbanyak yang digunakan yaitu daun sebanyak 24 spesies tumbuhan.

\section{Famili tumbuhan yang digunakan}

sebagai obat tradisional oleh

\section{Masyarakat Desa Manis Mata}

Famili tumbuhan yang digunakan sebagai obat tradisional oleh masyarakat Desa Manis Mata Kabupaten Ketapang sebanyak 26 famili dan yang paling banyak digunakan adalah zingiberaceae yaitu sebanyak 4 spesies tumbuhan.

\section{PEMBAHASAN}

Desa Manis Mata merupakan daerah dataran rendah yang moyaritas penduduknya bekerja sebagai nelayan. Daerah ini memiliki tingkat kepadatan penduduk yang merata. Fasilitas Kesehatan yang ada di Desa Manis Mata hanya terdapat satu pukesmas dengan dengan jumlah petugas Kesehatan yang masih kurang. Berdasarkan hasil penelitian 
Saputra, dkk. Biocelebes. Juni. 2021. Vol. 15 No. 1, 61-75

yang dilakukan, bahwa Berdasarkan hasil wawancara dengan masyarakat Desa Manis Mata didapatkan tumbuhan berpotensi sebagai obat yaitu terdiri 46 spesies dikelompokkan menjadi 26 famili.

Jenis tumbuhan obat yang digunakan sangat bervarasi mulai dari tingkat herba hingga pohon.Masyarakat Desa Manis Mata percaya dengan pengobatan tradisional dalam kehidupan sehari-hari. Warga yang sakit biasanya mencari pengobatan dengan cara menggunakan tumbuhan obat, mengambil air dilalu direbus, mengkonsumsi obat-obatan yang dijual bebas atau pergi ke pusat kesehatan desa pukesmans. Masyarakat setempat menanyakan cara pengobatan tradisional menggunakan tumbuhan obat kepada orang yang dianggap mengetahui tentang tumbuhan obat seperti dukun kampung, duku beranak, kepala adat dan orang yang mengetahui tentang tumbuhan obat.

Kepercayaan masyarakat Manis Mata terhadap pengobatan tradisional merupakan kepercayaan turun temurun. Hasil wawancara mengungkap bahwa sebagian besar responden yang berusia lebih dari 50-60 tahun, hanya mengenyam pendidikan dasar. Beberapa responden yang masih tergolong usia antara 20- 30 tahunan, berpendidikan SMP, SMA, D3 atau S1. Generasi muda umumnya percaya dan menggunakan tumbuhan obat setelah membuktikan khasiat dari tumbuhan obat tersebut. Responden dengan usia yang lebih tua menggunakan tumbuhan obat karena sudah percaya dan terbiasa menggunakan tumbuhan obat.

Masyarakat Desa Manis Mata mengenal 46 jenis tumbuhan yang dapat digunakan sebagai obat.Tumbuhan yang paling banyak digunakan adalah famili Zingiberaceae.Famili ini biasa digunakan oleh beberapa etnis di Indonesia sebagai bahan obat maupun bumbu masak. Zingiberaceae banyak digunakan oleh masyarakat manis mata dari etnis melayu,dayak,jawa dan tionghoa berdasarkan pengetahuan turun temurun, informasi dari tetangga atau media massa.

Rimpang Temulawak (Curcuma xanthorrhiza) pada saat wawancara dengan masyarakat Desa Manis Mata didapatkan informasi bahwa suku melayu,dayak,jawa da tionghoa digunakan masyarakat Manis Mata sebagai obat mempertahankan imunitas tubuh dan obat tipes. Tumbuhan dari golongan ini sangat familiar bagi masyarakat dan banyak dimanfaatkan sebagai pengobatan dan bumbu masakan (Nurcahyati dan Fuad, 2018).

Jenis tumbuhan obat yang digunakan sangat bervarasi mulai dari tingkat herba hingga pohon. Beberapa jenis penyakit yang disembuhkan dengan menggunakan tumbuhan tradisional. Tumbuhan yang digunakan untuk mengobati sakit mata yaitu yaitu sirih (piper betle (L) ) bagian daun yang digunakan dan airnya diminum dapat mengobati sakit mata dan kewanitaan. 
Tabel 1.Spesies tumbuhan yang digunakan sebagai obat tradisional oleh Masyarakat Desa Manis Mata

\begin{tabular}{|c|c|c|c|c|c|c|}
\hline \multirow[t]{2}{*}{ No } & \multicolumn{2}{|c|}{ Nama tumbuhan } & \multirow{2}{*}{$\begin{array}{l}\text { Bagian } \\
\text { tumbuhan }\end{array}$} & \multirow{2}{*}{$\begin{array}{c}\text { Cara } \\
\text { pengolahan }\end{array}$} & \multirow{2}{*}{$\begin{array}{c}\text { Cara } \\
\text { penggunaan }\end{array}$} & \multirow[t]{2}{*}{ Manfaat } \\
\hline & $\begin{array}{l}\text { Lokal/Indone } \\
\text { sia }\end{array}$ & Latin & & & & \\
\hline 1 & Tempuyung & $\begin{array}{l}\text { Sonchus } \\
\text { arvensis L. }\end{array}$ & $\begin{array}{l}\text { Daun dan } \\
\text { Akar }\end{array}$ & $\begin{array}{l}\text { Daun ditumbuk } \\
\text { dan ditempelkan } \\
\text { ke perut. } \\
\text { Akar dijemur dan } \\
\text { direbus lalu } \\
\text { diminum } \\
\text { daun dijemur } \\
\text { sampai kering } \\
\text { dan direbus lalu } \\
\text { diminum } \\
\end{array}$ & $\begin{array}{l}\text { Ditempel dan } \\
\text { diminum }\end{array}$ & $\begin{array}{l}\text { digunakan } \\
\text { mengobati } \\
\text { perut }\end{array}$ \\
\hline 2 & Ketepeng & $\begin{array}{l}\text { Cassia alata } \\
\text { L. }\end{array}$ & Daun. & $\begin{array}{l}\text { cara pengolahan } \\
\text { tumbuhan } \\
\text { ketepeng bagian } \\
\text { yang digunakan } \\
\text { daun ditumbuk } \\
\text { dan ditempelkan } \\
\text { pada bagian } \\
\text { yang terkena } \\
\text { kurap }\end{array}$ & Ditempelkan & $\begin{array}{lr}\text { digunan } & \text { untuk } \\
\text { mengobati } & \text { kurap } \\
\text { pada masing- } & \text { masing suku }\end{array}$ \\
\hline 3 & Pegage & $\begin{array}{l}\text { Centella } \\
\text { asiatica Urb. }\end{array}$ & $\begin{array}{l}\text { Daun dan } \\
\text { akar }\end{array}$ & $\begin{array}{l}\text { darah tinggi: } \\
\text { Dimakan } \\
\text { langsung (dibuat } \\
\text { lalapan) } \\
\text { kecerdasan serta } \\
\text { nafsu makan: } \\
\text { Ditumbuk dan } \\
\text { dicampurkan } \\
\text { dengan susu }\end{array}$ & $\begin{array}{l}\text { Diminum } \\
\text { dan lalapan } \\
\text { makan }\end{array}$ & $\begin{array}{l}\text { digunakan } \\
\text { menambah } \\
\text { makan } \\
\text { digunakan } \\
\text { kecerdasan } \\
\text {. }\end{array}$ \\
\hline 4 & Ati-ati & $\begin{array}{l}\text { Coleus } \\
\text { scutellarioid } \\
\text { es. }\end{array}$ & Daun & Daun direbus & Diminum & $\begin{array}{lr}\text { digunakan } & \text { untuk } \\
\text { mengobati } & \text { ngilu } \\
\text { pada kaki. } & \\
& \\
\text { digunakan } & \text { untuk } \\
\text { mengobati } & \text { sakit } \\
\text { kepala } & \\
\end{array}$ \\
\hline 5 & $\begin{array}{l}\text { Tapak } \\
\text { Leman }\end{array}$ & $\begin{array}{l}\text { Elephantopu } \\
\text { s scaber. }\end{array}$ & Akar & $\begin{array}{l}\text { Akar dibersihkan } \\
\text { dulu, setelah itu } \\
\text { direbus setelah } \\
10-15 \text { menit air } \\
\text { pada akar diambil } \\
\text { dan diminum. }\end{array}$ & Diminum & $\begin{array}{l}\text { digunakan untuk } \\
\text { mengobati sakit } \\
\text { perut } \\
\text { digunakan untuk } \\
\text { mengobati demam }\end{array}$ \\
\hline 6 & Kumis kucing & $\begin{array}{l}\text { Orthosiphon } \\
\text { spicatus. }\end{array}$ & Akar & $\begin{array}{l}\text { Akar dibersihkan } \\
\text { dulu, setelah itu } \\
\text { direbus setelah } \\
15 \text { menit air pada } \\
\text { akar diambil dan } \\
\text { diminum. }\end{array}$ & Diminum & $\begin{array}{lr}\text { digunakan untuk } \\
\text { mengobati tekanan } \\
\text { darah tinggi }\end{array}$ \\
\hline 7 & Sisirih & Paperomia & Daun dan & Akar dan daun & Diminum & Mengobati Sakit \\
\hline ISS & : 1978-6417 & ISCNE. 2580 & 991 & & & 65 \\
\hline
\end{tabular}


Saputra, dkk. Biocelebes. Juni. 2021. Vol. 15 No. 1, 61-75

pellucida $L$. akar dibersihkan dulu,

setelah itu

direbus setelah

10 menit air pada

daun dan akar

diambil dan

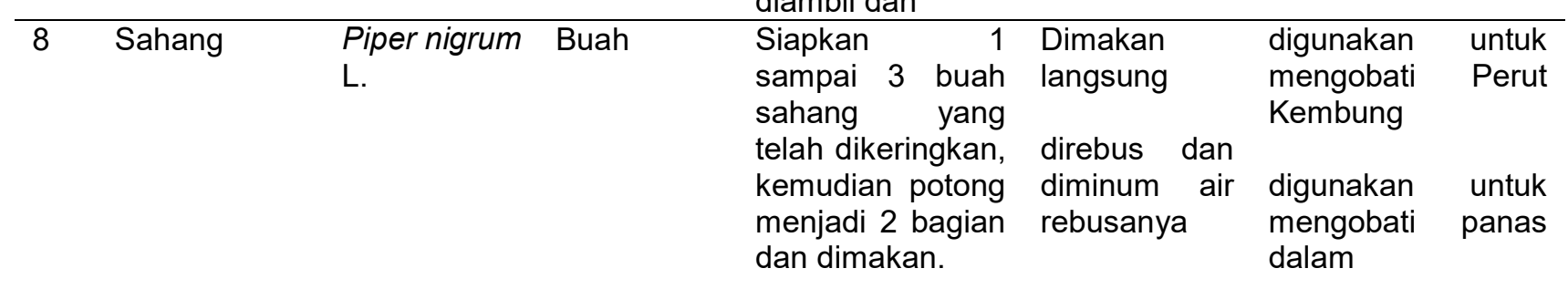

\begin{tabular}{|c|c|c|c|c|c|}
\hline & & & 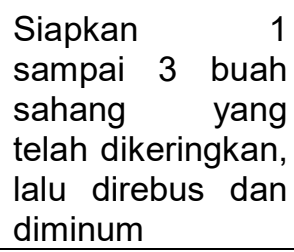 & & \\
\hline $9 \quad$ Putri malu & $\begin{array}{l}\text { Mimosa } \\
\text { pudica L. }\end{array}$ & Daun & $\begin{array}{l}\text { Siapkan } 1 \\
\text { genggam orang } \\
\text { dewasa daun } \\
\text { putri malu cuci } \\
\text { daun kemudian di } \\
\text { rebus dengan air } \\
\text { sekitar } 3 \text { gelas, } \\
\text { biarkan sehingga } \\
\text { medidih dan air } \\
\text { rebusan tersisa } 1 \\
\text { gelas, } \\
\text { selanjutnya air } \\
\text { rebusan disaring } \\
\text { dan diminum. }\end{array}$ & Diminum & $\begin{array}{l}\text { digunakan untuk } \\
\text { mengobati batuk }\end{array}$ \\
\hline $10 \quad$ Piyahong & $\begin{array}{l}\text { Anredera } \\
\text { cordifolia } \\
\text { (Ten) }\end{array}$ & Daun & $\begin{array}{l}\text { Mencegah tumor: } \\
\text { daun direbus dan } \\
\text { diminum airnya }\end{array}$ & $\begin{array}{l}\text { Diminum dan } \\
\text { ditempel }\end{array}$ & $\begin{array}{l}\text { digunakan untuk } \\
\text { Mencegah tumor } \\
\text { dan gatal-gatal } \\
\text { pada kulit }\end{array}$ \\
\hline
\end{tabular}

Obat gatal-gatal:

daun diremas

dandigosokkan

pada temapat

yang gatal.

\begin{tabular}{|c|c|c|c|c|c|c|}
\hline 11 & Sirih merah & $\begin{array}{l}\text { Piper } \\
\text { crocatum }\end{array}$ & Daun & $\begin{array}{lr}\text { Rebus } & 3-4 \\
\text { lembar daun } & \text { sirih } \\
\text { merah } & \text { dan } \\
\text { diminum } & \text { air } \\
\text { rebusanya. } & \end{array}$ & Diminum & $\begin{array}{l}\text { digunakan untuk } \\
\text { mengobati } \\
\text { kelesterol dan } \\
\text { Tekanan darah }\end{array}$ \\
\hline 12 & Sirih & Piper betle & Daun & $\begin{array}{l}\text { Daun direbus } 3-4 \\
\text { lembar dan } \\
\text { diteteskan pada } \\
\text { mata yang sakit } \\
\text { air rebusanya. } \\
\text { dimakan } \\
\text { langsung }\end{array}$ & $\begin{array}{l}\text { Diteteskan } \\
\text { diamakan } \\
\text { langsung }\end{array}$ & $\begin{array}{lr}\text { digunakan } & \text { untuk } \\
\text { mengobati } & \text { sakit } \\
\text { mata } & \\
\text { digunakan untuk } \\
\text { mengobati dan } \\
\text { menghilangkan bau } \\
\text { badan. }\end{array}$ \\
\hline 13 & Bunga melati & $\begin{array}{l}\text { Jasminum } \\
\text { multiflorum } \\
\text { Andr. }\end{array}$ & $\begin{array}{l}\text { Daun dan } \\
\text { bunga }\end{array}$ & $\begin{array}{l}\text { diulek, } \\
\text { tambahkan } \\
\text { kemenyan dan }\end{array}$ & Ditempelkan & $\begin{array}{l}\text { digunakan untuk } \\
\text { mengobati Demam }\end{array}$ \\
\hline
\end{tabular}

ISSN-P : 1978-6417; ISSN-E : 2580-5991 
Saputra, dkk. Biocelebes. Juni. 2021. Vol. 15 No. 1, 61-75

diusapkan

\begin{tabular}{|c|c|c|c|c|c|c|}
\hline 14 & Pandan & $\begin{array}{l}\text { Pandanus } \\
\text { tectorius } \\
\text { Park. }\end{array}$ & Daun & $\begin{array}{l}\text { Daunnya diulek } \\
\text { dan ditambah } \\
\text { dengan sedikit air } \\
\text { dan usapkan } \\
\text { pada dahi. }\end{array}$ & Ditempelkan & $\begin{array}{l}\text { digunakan untuk } \\
\text { mengobati Demam }\end{array}$ \\
\hline 15 & Cengkodok & $\begin{array}{l}\text { Melastoma } \\
\text { polyanthum } \\
\text { Bl. }\end{array}$ & & $\begin{array}{l}\text { Untuk mengobati } \\
\text { sakit perut: Daun } \\
\text { direbus dan } \\
\text { diminum airnya }\end{array}$ & Diminum & $\begin{array}{l}\text { digunakan untuk } \\
\text { mengobati sakit } \\
\text { perut, } \\
\text { digunakan untuk } \\
\text { mengobati demam }\end{array}$ \\
\hline 16 & Kaca beling & $\begin{array}{l}\text { Strobilanthe } \\
\text { s crispus } \\
\text { Blume }\end{array}$ & Daun & $\begin{array}{lr}\text { Ambil daun kaca } \\
\text { beling } & \text { segar } \\
\text { sebanyak } & 25 \\
\text { gram, direbus } \\
\text { dengan } 2 \text { gelas } \\
\text { air selama } 15 \\
\text { menit. Setelah } \\
\text { dingin di saring } \\
\text { kemudian } \\
\text { diminum }\end{array}$ & Diminum & $\begin{array}{l}\text { digunakan untuk } \\
\text { mengobati batu } \\
\text { ginjal dan liver } \\
\text { digunakan untuk } \\
\text { mengobati kencing } \\
\text { manis }\end{array}$ \\
\hline 17 & Sirih merah & $\begin{array}{l}\text { Piper } \\
\text { ornatum }\end{array}$ & Daun & $\begin{array}{l}\text { Sirih dioleskan } \\
\text { pada bagian } \\
\text { yang sakit dan } \\
\text { diminum }\end{array}$ & $\begin{array}{l}\text { Dioleskan } \\
\text { Diminum }\end{array}$ & $\begin{array}{lr}\text { digunakan } & \text { untuk } \\
\text { mengobati radang } \\
\text { panas. } \\
\text { digunakan untuk } \\
\text { mengobati tekanan } \\
\text { darah tinggi }\end{array}$ \\
\hline 19 & Ambing buah & $\begin{array}{l}\text { Premna } \\
\text { corymbose } \\
\mathrm{R}\end{array}$ & Daun & $\begin{array}{l}\text { Daun ditumbuk } \\
\text { sampai halus dan } \\
\text { dioleskan } \\
\text { dibagian tubuh. }\end{array}$ & Dioleskan & $\begin{array}{l}\text { digunakan untuk } \\
\text { mengobati Demam }\end{array}$ \\
\hline 20 & Putar wali & $\begin{array}{l}\text { Tinospora } \\
\text { tuberculata } \\
\text { Beumee. }\end{array}$ & Akar & $\begin{array}{l}\text { Potong batang } \\
\text { sampai } 2-3 \mathrm{~cm} \\
\text { batang browali di } \\
\text { rebus } \\
\text { menggunakan air } \\
\text { setelah direbus } \\
\text { disaring dan } \\
\text { diminum airnya. }\end{array}$ & Diminum & $\begin{array}{l}\text { digunakan } \\
\text { mengobati } \\
\text { kolesterol }\end{array}$ \\
\hline 21 & Rangit & $\begin{array}{l}\text { Passiflora } \\
\text { foiteda L. }\end{array}$ & Buah & $\begin{array}{l}\text { Buah yang sudah } \\
\text { matang berwarna } \\
\text { kuning dan } \\
\text { dimakan } \\
\text { langsung }\end{array}$ & Dimakan & $\begin{array}{l}\text { digunakan } \\
\text { mengobati } \\
\text { ginjal }\end{array}$ \\
\hline 22 & $\begin{array}{l}\text { Kembang } \\
\text { sepatu }\end{array}$ & $\begin{array}{l}\text { Hibiscus } \\
\text { rosa- } \\
\text { sinensis L. }\end{array}$ & Bunga & $\begin{array}{lr}\text { Bunga } & \text { direndam } \\
\text { kedalam } & \text { segelas } \\
\text { air selama } 8 \text { jam } \\
\text { setalah } 8 \text { jam } \\
\text { bunga } & \text { diremas } \\
\text { dan } & \text { disaring } \\
\text { airnya, oleskan } \\
\text { kebagian } & \text { rambut } \\
\text { dan } & \text { tunggu } \\
\text { sampai } & 5 \text { menit } \\
\text { dan } & \text { bilas } \\
\text { menggunakan air }\end{array}$ & Dioleskan & $\begin{array}{lr}\text { digunakan untuk } \\
\text { mengobati ketombe }\end{array}$ \\
\hline
\end{tabular}




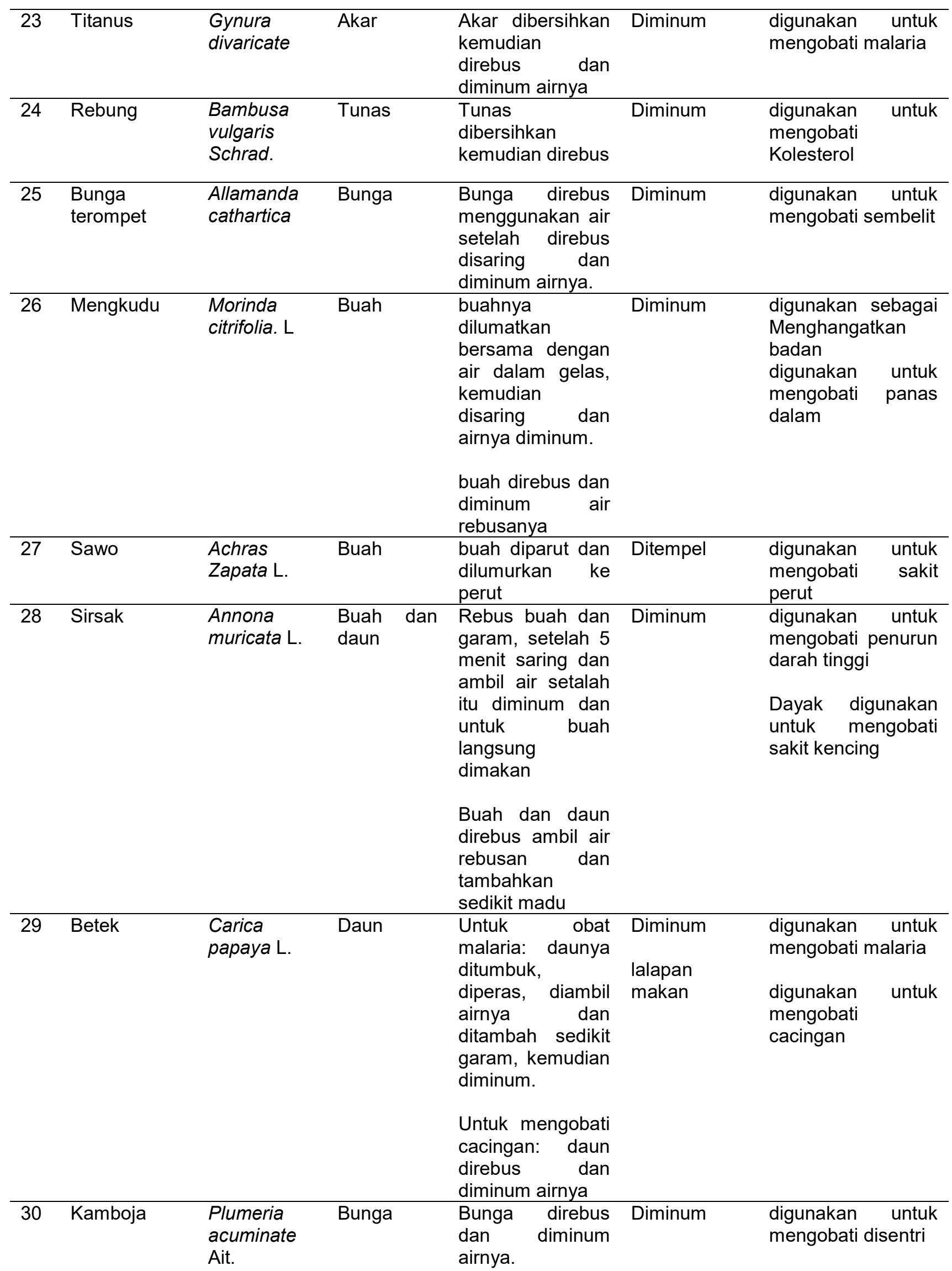




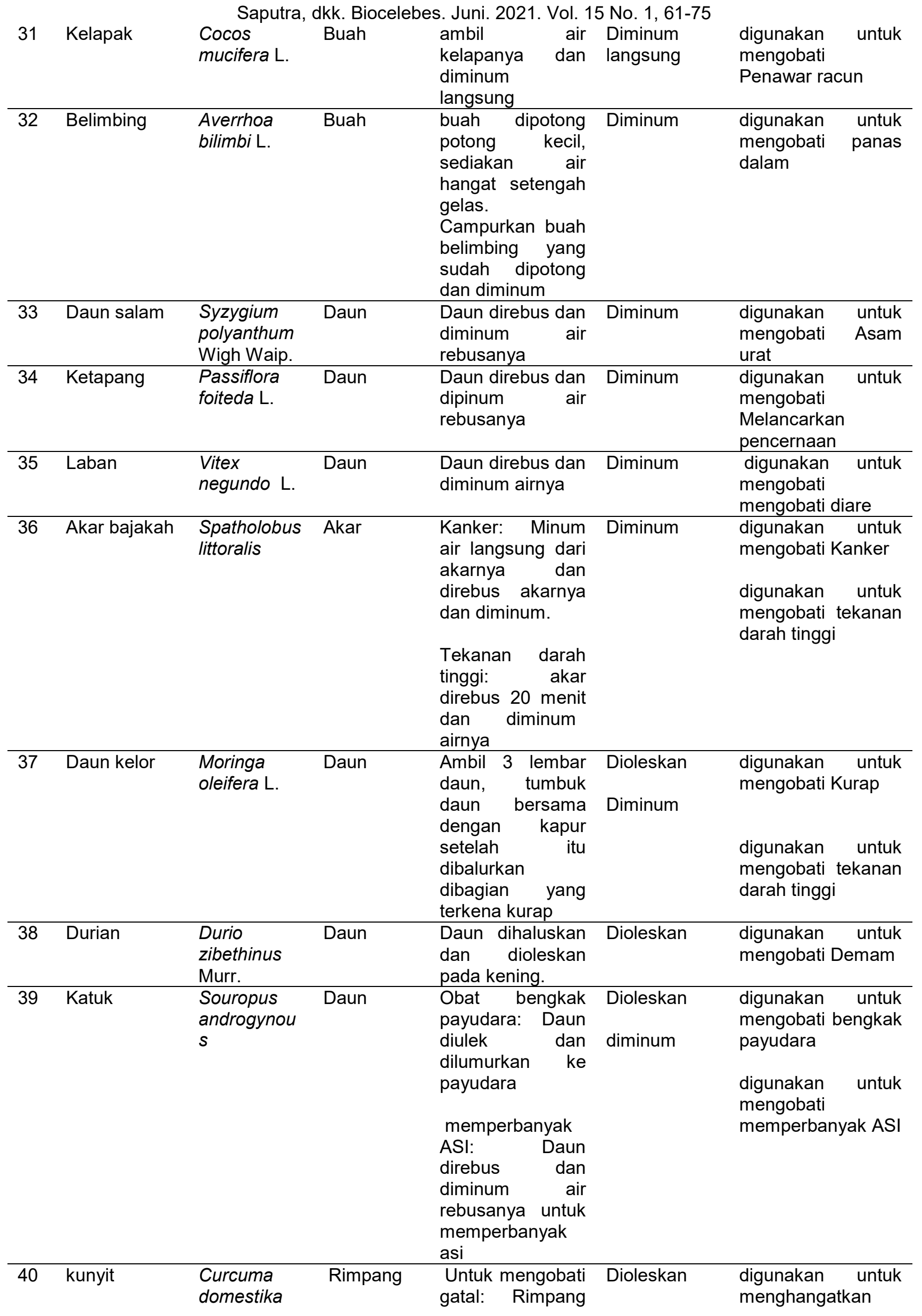


Saputra, dkk. Biocelebes. Juni. 2021. Vol. 15 No. 1, 61-75

\begin{abstract}
Val.
\end{abstract}

\section{diulek
ditambahkan}

sedikit air,

lumurkan pada

seluruh tubu

menghangatkan

badan: Rimpang

diiris tipis-tipis,

seduh dan

minum airnya

\begin{tabular}{lll}
\hline 41 Kencur & $\begin{array}{l}\text { Kaemperia Rimpang } \\
\text { galanga. }\end{array}$
\end{tabular}

$\begin{array}{lll} & & \\ & & \\ & \text { Keladi merah } & \begin{array}{l}\text { Caladium } \\ \text { bicolor } \\ \text { (Wait) vent. }\end{array} \\ & & \\ & & \end{array}$

\begin{tabular}{llll}
\hline 43 & Temu hitam & $\begin{array}{l}\text { Curcuma } \\
\text { Aeruginosa } \\
\text { Roxb }\end{array}$ & Rimpang \\
& &
\end{tabular}

Untuk mengobati

batuk pada bayi:

Rimpang diparut, peras, diletakkan disendok

ditambah madu

dan minumkan ke

bayi

Untuk

mengoabati bisul:

daun ditumbuk

dan ditempelkan

ke bisul

Umbi ditumbuk

hingga halus dan

ditempel pada

bagian tubuh

yang bengkak

Membantu

membuang racun

dalam tubuh:
Parut rimpang

temu

hitam

peras

hasil

parutan

dan minum

pagi dan malam.

Obat ambeien:

Umbi

bakar

agak

5-6cm,

hingga

kehitama

$\mathrm{n}$ dan tumbuk

hingga halus

campurk

an dengan air

hangat setelah itu

saring dan

minum airnya

\begin{tabular}{|c|c|c|c|c|c|c|c|}
\hline 44 & Keladi tikus & $\begin{array}{l}\text { Typhonium } \\
\text { flagelliforme } \\
\text { L. }\end{array}$ & Daun & $\begin{array}{lr}\text { Daun direbus dan } \\
\text { disaring } & \text { setelah } \\
\text { itu } & \text { diminum } \\
\text { airnya } & \\
\end{array}$ & Diminum & $\begin{array}{l}\text { digunakan } \\
\text { mengobati } \\
\text { payudara }\end{array}$ & $\begin{array}{r}\text { untuk } \\
\text { kanker }\end{array}$ \\
\hline 45 & $\begin{array}{l}\text { Kemale } \\
\text { hujan }\end{array}$ & $\begin{array}{l}\text { Drymogloss } \\
\text { um } \\
\text { piloselloide } \\
\text { Presl. }\end{array}$ & Daun & $\begin{array}{l}\text { Daun sisik naga } \\
\text { direbus } \\
\text { menggunakan air } \\
\text { dan diminum }\end{array}$ & Diminum & $\begin{array}{l}\text { digunakan } \\
\text { mengobati } \\
\text { Reumatik }\end{array}$ & untuk \\
\hline
\end{tabular}

$\begin{array}{lll}\begin{array}{l}\text { Diminum dan } \\ \text { ditempelkan }\end{array} & \begin{array}{l}\text { digunakan } \\ \text { mengobati } \\ \text { pada bayi }\end{array} \\ & \text { batuk } \\ & \text { digunakan untuk } \\ & \text { mengobati bisul }\end{array}$

Ditempel

digunakan untuk

mengobati

Bengkak

Membantu

membuang racun

dalam tubuh

dioleskan

kebagian

anus

digunakan untuk

mengobati

ambeien badan

digunakan untuk mengobati gatalgatal 
airnya

\begin{tabular}{|c|c|c|c|c|}
\hline $46 \begin{array}{l}\text { Entemu } \\
\text { orange }\end{array}$ & Rimpang & $\begin{array}{l}\text { rimpang temu } \\
\text { orange peras } \\
\text { hasil dari } \\
\begin{array}{l}\text { parutan } \\
\text { dan minum } \\
\text { pagi dan malam. }\end{array}\end{array}$ & Diminum & $\begin{array}{l}\text { digunakan untuk } \\
\text { mengobati atau } \\
\text { Mempertahankan } \\
\text { imunitas tubuh }\end{array}$ \\
\hline
\end{tabular}

Sirih (piper betle L) menurut hasil wawancara masyarakat Desa Manis Mata yang dimana sirih dimanfaatkan suku melayu dan Dayak. Suku melayu memanfaatkan sirih untuk mengobati sakit mata. Selain itu suku Dayak memanfaatkan daun sirih (Piper betle $\mathrm{L}$ ) untuk mehilangkan bau badan secara pengolahan tumbuhan suku melayu direbus dulu sedangkan suku dayak dimakan langsung. Pada penelitian (Almida, 2015) pada suku dayak yang berada di Sanggau tentang Pemanfaatan Tumbuhan Obat Pada Masyarakat Suku Dayak Jangkang Tanjung Di Desa Ribau Kecamatan Kapuas Kabupaten sanggau memanfaatkan sirih untuk mengurangi ASI berlebih.

Sementara itu masyarakat Desa Manis Mata juga mengenal jenis tumbuhan yaitu mengkudu (Morinda citrifolia (L) ) yang dimanfaatkan oleh 2 suku yaitu Melayu dan Dayak, suku Melayu menggunakan mengkudu sebagai obat tekanan darah tinggi dan suku Dayak menggunakan mengkudu sebagai panas dalam. Selain dari manfaat yang berbeda cara pengolahan dari suku Melayu dan Dayak sangat berbeda yang dimana suku Melayu mengolah buah mengkudu direbus lalu diminum sedangkan suku Dayak buahnya dilumatkan bersama dengan air dalam gelas kemudian disaring dan diminum airnya. ISSN-P : 1978-6417; ISSN-E : 2580-5991
Pada penelitian (Reynaldi, 2019) pada suku Dayak yang berada di Bakumpai kalimantan Tengah tentang Etnobotani Tanaman Obat Oleh Masyarakat Dayak Bakumpai Di Desa Muara Ripung Kecamatan Dusun Selatan Kabupaten Barito Selatan. Yang menggunakan Mengkudu (Morinda citrifolia (L) ) untuk mengobati tekanan darah tinggi sedangkan suku Dayak diderah Desa Manis Mata menggunakan Mengkudu untuk mengobati panas dalam.

Keji beling (Strobilanthes crispus) berdasarkan wawancara masyarakat Desa Manis Mata bahwa tumbuhan ini berkhasiat mengatasi kencing batu dan liver. Untuk cara pengolahan kaca beling suku Melayu dan suku Dayak hampir sama, bagian yang diambil adalah daun kaca beling sebanyak 25 gram, dan suku Dayak sebanyak 5-7 lembar lalu direbus dengan 2 gelas air selama 15 menit setelah dingin disaring dan diminum sedangkan untuk manfaatnya suku Melayu mengobati ginjal dan liver dan suku Dayak mengobati kencing manis. Pada penelitian Nurlaila, (2017) pemanfaatan suku Melayu yang berada di sulawesi selatan tentang Etnobotani Tumbuhan Yang Digunakan Dalam Pengobatan Tradisional Di Kecamatan Sinjai Selatan Kabupaten Sinjai Sulawesi Selatan 
Saputra, dkk. Biocelebes. Juni. 2021. Vol. 15 No. 1, 61-75

yang dimana masyarakat sinjai menggunakan

keji beling sebagai hipertensi, sedangkan cara pengolahan daun keji beling direbus bersama daun alpukat kemudian diminum. Berbeda dengan suku Melayu didesa Manis Mata menggunkan keji beling untuk mengobati ginjal dan liver.

Bajakah (Spatholobus littoralis) berdasarkan wawancara masyarakat Desa Manis Mata diperoleh empat suku yang memanfaatkan tumbuhan bajakah sebagai obat tradisional masing-masing suku berbeda-beda dalam cara pengolahan dan pemanfaatan tumbuhan obat terdapat suku Melayu, Dayak, Tionghoa dan Jawa langsung meminum air dari akarnya dan direbus akarnya. Sedangkan suku Tionghoa dan Melayu akarnya direbus selama 20 menit dan diminum airnya. Manfaat tumbuhan obat masing-masing suku berbeda dari suku Dayak dan Jawa sebagai obat kanker sedangkan suku Melayu dan Tionghoa dapat mengobati kanker dan tekanan darah tinggi. Bajakah merupakan bagian akar dari tumbuhan yang berfungsi sebagai sumber air minum, bajakah juga memiliki berbagai fungsi obat-obatan lain, seperti adanya kandungan anti oksidan dan senyawa yang membunuh sel tumor dan kanker (Joanita dan Evi, 2020).

Suruhan (Peperomia pellucida $\mathrm{L}$ ) atau dikenal oleh masyarakat sekitar dengan nama sisirih menurut hasil wawancara dengan masyarakat Desa Manis Mata Kabupaten Ketapang terdapat 4 suku yaitu Jawa, Melayu, Dayak dan Tionghoa dari masing-masing suku ada yang mengenal adapun yang tidak mengenal suruhan/sisirih berdasarkan wawancara yang didapat suku Melayu dan suku Dayak ISSN-P : 1978-6417; ISSN-E : 2580-5991 mengenal dan memanfaatkan

tumbuhan tersebut untuk mengobati sakit pinggang dan panas dalam. Untuk cara pengolahannya suku Melayu dan Dayak menggunakan akar dan daun dibersihkan dulu setelah itu direbus selama 10 menit saring hasil rebusan diminum. Untuk manfaat untuk pengobatan suku Melayu. mengobati perut kembung sedangkan suku Dayak mengobati panas dalam. Tarigan et al. (2012) melaporkan bahwa ekstrak etanol herba suruhan mempunyai efek antihiperurisemia terhadap mencit. Berbeda dengan penelitian (Nurlaila sari dkk, 2017) yang dimana suruhan diambil daun dan batang lalu dihaluskan kemudian dijadikan masker pada wajah. Suruhan memiliki kandungan antioksidan yang tinggi.

Pemanfaatan tumbuhan yang dilakukan oleh masyarakat Desa Manis Mata ataupun masyarakat lain umumnya memiliki cara ataupun bahan pengobatan yang berbedabeda antara satu dan yang lainnya tergantung pada jenis penyakit yang diobati dan kepercayaan yang sudah turun-temurun diperoleh. Berdasarkan aspek etnobotani di Desa Manis Mata menggunakan suruhan (Paperomia pellucida L) sebagai bahan dalam mengobati sakit pinggang dan panas dalam dengan cara daun dan akar direbus dan diminum airnya. Hal ini berbeda dengan pengobatan yang dilakukan oleh Masyarakat di Kecamatan Sinjai Selatan Kabupaten sinjai Sulawesi Selatan (Nurlaila Sari, dkk 2017) dimana tanaman suruhan (Paperomia pellucida) yang digunakan untuk masker wajah. 
Titanus/Daun Dewa (Gynura segetum L) menurut hasil wawancara masyarakat Desa Manis Mata tumbuhan tersebut mampu mengatasi demam dan malaria. Berdasarkan pemanfaatanya terdapat dua suku yang menggunakan daun dewa yaitu suku Melayu dan Dayak menggunakan daun titanus sebagai obat tradisional untuk cara pengolahannya akar dibersihkan kemudian dijemur dan direbus lalu diminum airnya. Diantara bahan alami sangat potensial untuk dikembangkan sebagai insektisida hayati adalah tanaman titanus atau daun dewa (Gynura pseudochina L) tanaman ini mengandung komposisi senyawa alkaloid, flavonoid, tannin galat, saponin, dan steroid/triterpenoid, serta 20 minyak atsiri. Semua senyawa tersebut bersifat toksid dan terbukti berkhasiat sebagai insektisida, ecdysone blocker, repolen, dan anti feedant pada serangga.

Sementara itu masyarakat Desa Manis Mata juga menggunakan atau mengenal jenis tumbuhan yaitu Piyahung/Binahong (Anredera cordifolia Ten) untuk mencegah tumor dan gatal-gatal pada kulit. berbeda Pada penelitian Etnobotani Tumbuhan Obat Suku Melayu Desa Durian Sebatang Kecamatan Seponti Kabupaten Kayong Utara tumbuhan obat obat yang digunakan oleh masyarakat Desa Durian Sebatang yaitu binahong memanfatkan binahong untuk melancarkan haid, diabetes dan asam urat. dan untuk bagian yang digunakan daun selain itu cara pengolahan direbus dan diminum.

Pada penelitian Nurlaila, (2017) pemanfaatan suku Melayu yang berada di sulawesi selatan ISSN-P : 1978-6417; ISSN-E : 2580-5991 tentang Etnobotani

Tumbuhan Yang Digunakan Dalam Pengobatan Tradisional Di Kecamatan Sinjai Selatan Kabupaten Sinjai Sulawesi Selatan yang dimana suku Melayu sinjai menggunakan binahong sebagai penyakit dalam, sedangkan cara pengolahan daun binahong direbus kemudian diminum. Berbeda dengan suku Melayu didesa Manis Mata menggunakan binahong untuk mengobati untuk mencegah tumor dan gatalgatal pada kulit.

Masyarakat Desa Manis Mata juga menggunakan atau mengenal jenis tumbuhan yaitu Temulawak Hitam (Curcuma Aeruginosa Roxb) untuk membuang racun dalam tubuh menurut informan suku Melayu sedangkan untuk informan suku Tionghoa digunakan untuk mengobati ambeien. Sedangkan untuk cara pengolah suku Tionghoa rimpang diambil 5-6 cm, bakar hingga kehitaman dan tumbuk hingga halus lalu masukkan kedalam air panas 15 menit setelah dingin saring temulawak yang sudah dimasukkan kedalam gelas diminum. Temulawak ini sering digunakan didesa Manis Mata dan Temulawak Hitam sangat sulit didapat dipasar maupun dicari ke hutan yang dimana masyarakat Desa Manis Mata banyak melestarikan atau menanam temulawak diperkarangan rumah.

Berbeda pada penelitian (Ari Kurniarum, 2016) dalam penelitian penggunaan tanaman obat tradisional untuk meningkatkan nafsu makan pada balita yang menyatakan bahwa untuk meningkatkan nafsu makan pada balita adalah temu hitam dengan jumlah 22 responden $(61,1 \%)$. Temulawak hitam memiliki efek yang bagus pada usus halus. Khasiat 
Saputra, dkk. Biocelebes. Juni. 2021. Vol. 15 No. 1, 61-75

Antispasmodic yang ditunjukkan oleh sodium curcuminate telah di teliti pada usus halus marmut.

Masyarakat Desa Manis Mata juga menggunakan atau mengenal jenis tumbuhan yaitu Pegage (Centella asiatica Urb) mengobati tekanan darah tinggi dan menambah nafsu makan, pada saat wawancara dengan masyarakat suku Melayu dan suku Dayak tentang pemanfaatan tumbuhan obat didapatkan bahwa suku Melayu dan suku Dayak menggunakan pegage sebagai obat dan lalapan makan. Untuk suku Melayu menggunakan pegage untuk mengobati tekanan darah tinggi sedangkan pada suku Dayak untuk daya ingat yang kuat.

Pada penelitian Amelia, (2019) Tentang Etnobotani Dan Penggunaan Tumbuhan Liar Sebagai Obat Tradisional Oleh Masyarakat Suku Madura Kecamatan Lenteng Desa Bluto menggunakan semua bagian tumbuhan pegagan dimanfaatkan untuk mengobati kelainan ginjal, hipertensi, keropos tulang, kelainan paru-paru, kejang dan migran untuk cara pengoalahannya direbus dan diambil sarinya. Sedangkan pada Desa Manis Mata untuk manfaatnya sebagai obat tekanan darah tinggi, nafsu makan dan untuk kecerdasan. Selain itu suku Dayak, suku Melayu dan suku Tionghoa. pengolah tanaman ini biasanya dibuat Ialapan makan dan ditumbuk dan dimasukkan kedalam air dingin.

Pegagan (Centella asiatica (L.) Urban) merupakan tanaman liar yang mempunyai prospek cukup baik sebagai tanaman obat. Winarto. Obat tradisional adalah obat-obatan ISSN-P : 1978-6417; ISSN-E : 2580-5991 yang diolah secara tradisional, turun temurun, berdasarkan resep nenek-moyang, adatistiadat, kepercayaan, atau kebiasaan setempat, baik bersifat magic maupun pengetahuan tradisional (LIPI 2016).

\section{DAFTAR PUSTAKA}

Amelia, (2019). Etnobotani Dan Penggunaan Tumbuhan Liar Sebagai Obat Tradisional Oleh Masyarakat Suku Madura Kecamatan Lenteng Desa Bluto. Fakultas Pertanian Universitas Wiraraja.

Almida S. Riza Linda dan Irwan Lovadi. (2015). Pemanfaatan Tumbuhan Obat Pada Masyarakat Suku Dayak Jangkang Tanjung Di Desa Ribau Kecamatan Kapuas Kabupaten Sanggau. (Jurnal Protobion). Vol.4(2) :1-8 (diakses tanggal 16 Febuari 2021).

Ari. K., \& Rizky A. N. (2016). Penggunaan Tanaman Obat Tradisional Untuk Meningkatkan Nafsu Makan Pada Balita. Kementerian Kesehatan Politeknik Kesehatan Surakarta Jurusan Kebidanan.

Haryono, Wardenar dan Yusro, (2014). Etnobotani Tumbuhan Obat Didesa mangkiang Kecamatan Sanggau Kapuas Kabupaten Sanggau. Jurnal Pendidikan dan Pembelajaran Biologi. 1(1). (online) (http://journal.student.uny.ac.id/ojs/ind x.php/pbio/article/view/4627/4294diakse s tanggal 23 Agustus 2019).

Joanita, J \& Evi. (2020). Perlindungan Hak Kekayaan Intelektual Bagi Tanaman Obat Tradisional Di Provinsi Kalimantan Tengan. Fakultas Hukum Palangka Raya.

LIPI. 2016. Tanaman Obat Indonesia Pegagan. LIPI, Jakarta. http://www.iptek.net.id, [18 November 2020].

Nurcahyati, N \& Fuad, A. 2018. Kajian Etnobotani Tanaman Zingiberaceae Pada Masyarakat Suku Using 
Kabupaten Banyuwangi. Biosense 1 (1): 24-35.

Nurlaila S. dkk, (2017). Etnobotani Tumbuhan Yang Digunakan Dalam Pengobatan Tradisional Di Kecamatan Sinjai Selatan Kabupaten Sinjai Sulawesi Selatan. Jurusan Biologi, Fakultas Sains dan Teknologi, UIN Alauddin Makassar.

Reynaldi, Rahmadi. A \& Arryati. H (2019). Etnobotani Tanaman Obat Oleh Masyarakat Dayak Bakumpai Di Desa Muara Ripung Kecamatan Dusun Selatan Kabupaten Barito Selatan. Fakultas Kehutanan Universitas Lambung Mangkurat.

Tarigan, I.M. br, S. Bahri dan A. Saragih.
2012. Aktivitas

Ekstrak (Peperomia pellucida (L.) Kunth) Pada Mencit Jantan. Journal of Pharmaceutics and Pharmacology 1(1):37-43. 